\title{
Lateral Thoracic Lung Herniation: A Rare Condition
}

\section{Lateral Torasik Akciğer Herniasyonu: Nadir Bir Durum}

Erkan Akar' ${ }^{1}$, Miktat Arif Haberal' ${ }^{1}$ Özlem Şengören Dikiş²

\begin{abstract}
Lung herniation is described as the protrusion of lung tissue and pleura out of the thoracic cavity through an abnormal gap in the chest wall. We present a case with a rare lateral lung herniation. The patient was taken for urgent surgery and an anterolateral thoracotomy was carried out. Pursuant to rib and lung parenchyma repair, the herniation defect was closed without a prosthetic graft. The patient was discharged on the postoperative fifth day with full recovery. Although there is a lack of consensus on the timing of surgery, we are of the opinion that in blunt thorax trauma-induced symptomatic lung hernias, operating on the patient is appropriate as soon as a diagnosis is established should be advised.
\end{abstract}

Key words: Lung herniation, chest wall, trauma, thoracotomy.

\section{Özet}

Akciğer herniasyonu, göğüs duvarındaki anormal bir açıkıktan akciğer dokusu ve plevranın toraks kavitesi dışına çıkması olarak tanımlanır. Burada, nadir görülen lateral akciğer hernili bir olguyu sunduk. Hasta acil ameliyata alınarak anterolateral torakotomi yapıldı. Kaburga ve akciğer parankim tamirinin ardından prostetik greft kullanmadan herni defekti kapatıldı. Hasta postoperatif beşinci günde şifa ile taburcu edildi. Cerrahinin zamanlaması konusunda tam bir fikir birliği bulunmamasına rağmen, künt toraks travmasına bağlı gelişen semptomatik akciğer hernilerinde, tanı konulduğu anda ameliyat yapılmasının uygun olduğunu düşünmekteyiz.

Anahtar Sözcükler: Akciğer hernisi, göğüs duvarı, travma, torakotomi.
'Department of Thoracic Surgery, Health Sciences University, Bursa Yuksek Ihtisas Training ad Research Hospital, Bursa, Turkey ${ }^{2}$ Department of Pulmonary Diseases, Health Sciences University, Bursa Yuksek Ihtisas Training and Research Hospital, Bursa, Turkey
'Sağlık Bilimleri Üniversitesi, Bursa Yüksek İhtisas Eğitim ve Araştırma Hastanesi, Göğüs Cerrahisi Kliniği, Bursa ${ }^{2}$ Sağlık Bilimleri Üniversitesi, Bursa Yüksek İhtisas Eğitim ve Araştırma Hastanesi, Göğüs Hastalıkları Kliniği, Bursa

Submitted (Başvuru tarihi): 03.01.2019 Accepted (Kabul tarihi): 10.04.2019

Correspondence (iletişim): Erkan Akar, Department of Thoracic Surgery, Health Sciences University, Bursa Yuksek Ihtisas Training ad Research Hospital, Bursa, Turkey

e-mail: drerkanakar@hotmail.com 
Lung herniation is an atypically occurring incident that can be described as a pleura and/or lung tissue protrusion due to a thoracic wall irregularity (1). Nearly $50 \%$ of herniation cases are caused by a trauma, whereas $20 \%$ of all cases arise from congenital imperfections, and almost $30 \%$ of cases develop ad libitum. Conditional incidents of herniation are a result of intercostal muscle fragility together with abruptly incrementing intrathoracic pressure (2).

Although direct injuries of the thorax resulting from a potent forceful impact such as a car crash are the primary etiological cause of lung herniation, the development of complications pursuant to thoracotomy procedures is also conceivable (2). Frontal thorax which is the area of predilection regarding the herniation of lung is not withstanding to the origin (3). Owing to the difficulty in perceiving such symptoms as pliant, susceptive-to-pain, subdermal bulks or displays of breathing-mediated enlargement, establishing a clinical diagnosis can be difficult. Consequently, to establish an accurate diagnosis, although an X-ray of the chest may prove useful, a timely computerized tomography (CT) scan is obligatory.

\section{CASE}

Lung herniation is an atypically occurring incident that can be described as a pleura and/or lung tissue protrusion due to a thoracic wall irregularity (1). Nearly 50\% of herniation cases are caused by a trauma, whereas $20 \%$ of all cases arise from congenital imperfections, and almost $30 \%$ of cases develop ad libitum. Conditional incidents of herniation are a result of intercostal muscle fragility together with abruptly incrementing intrathoracic pressure (2).

Although direct injuries of the thorax resulting from a potent forceful impact such as a car crash are the primary etiological cause of lung herniation, the development of complications pursuant to thoracotomy procedures is also conceivable (2). Frontal thorax which is the area of predilection regarding the herniation of lung is not withstanding to the origin (3). Owing to the difficulty in perceiving such symptoms as pliant, susceptive-to-pain, subdermal bulks or displays of breathing-mediated enlargement, establishing a clinical diagnosis can be difficult. Consequently, to establish an accurate diagnosis, although an $X$-ray of the chest may prove useful, a timely computerized tomography (CT) scan is obligatory.

Haemopneumothorax in the left lung, subcutaneous emphysema and a fracture of the 7 th rib were identified in posteroanterior chest radiography (PA). A CT scan of the thorax was carried out in order to determine the anatomical correlation of herniated lung tissue, thoracic wall muscles and intercostal muscles. The CT scan showed a haemopneumothorax on the left side, a herniated lower lobe through the 7th intercostal space, and a displaced lateral fracture of the 7th rib (Figure 1 and 2).

Upon the escalation of dyspnea and chest pain, and the deterioration of patient's vital signs $(85 / 50 \mathrm{mmHg}$ blood pressure, $78 \%$ oxygen saturation), an immediate surgery decision was made. After single lumen endotracheal intubation, the patient placed on the operation table in left anterolateral position. A thoracotomy was carried out at the site of lung hernia and the fluctuating dermis. The thorax was reached via the 7 th intercostal space. A surgical exploration revealed a displaced fracture of the 7 th rib from the lateral area and a herniated lung through this space. It was also observed that the fractured structures of the rib had incised the lower lobe of the lung, and that the incision reached the fissure. No major vascular injuries were detected. The herniated lung tissue was reduced into the thorax cavity, no and incarceration was observed on the tissue. An approximately 500 cc hematoma was tapped from the thorax cavity. Lacerations to the pulmonary parenchyma were repaired with 2/0 vicryl. Air leak and bleeding were controlled, the displaced 7th rib fragments were brought end-to-end with 1/0 silk suture. A defect in the skeletal structure was retracted with 1/0 silk suture. A $32 \mathrm{~F}$ intercostal drain was placed inside the lung apex. The herniation site was supported by the surrounding muscle tissues, and no prosthetic graft was used. The patient was taken into the postoperative intensive care unit. After a stable general condition was attained, the patient was taken to service after one day. On the third day, upon the expansion of the lung and nonexistent drainage, the intercostal drain was removed (Figure 3). The patient was discharged. No complications were observed during one-, three- and six-month follow ups.

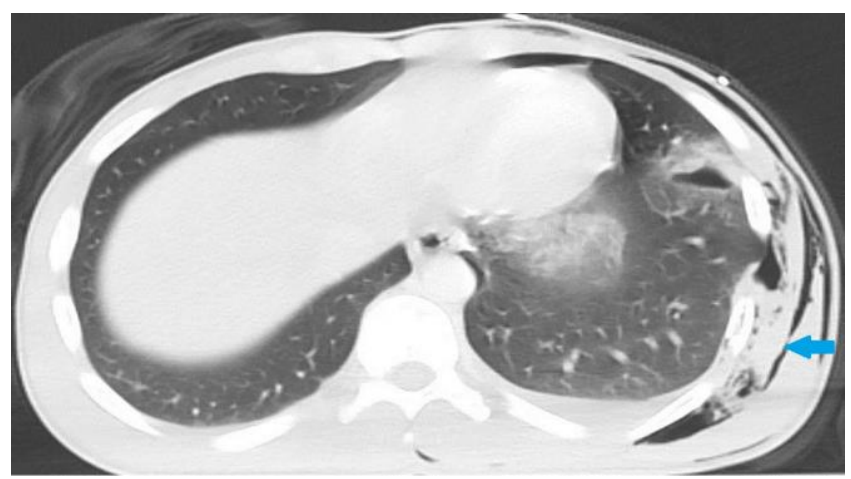

Figure 1: In computerized tomography of thorax, hemothorax in the left lung, subcutaneous emphysema, traumatic pulmonary cyst 


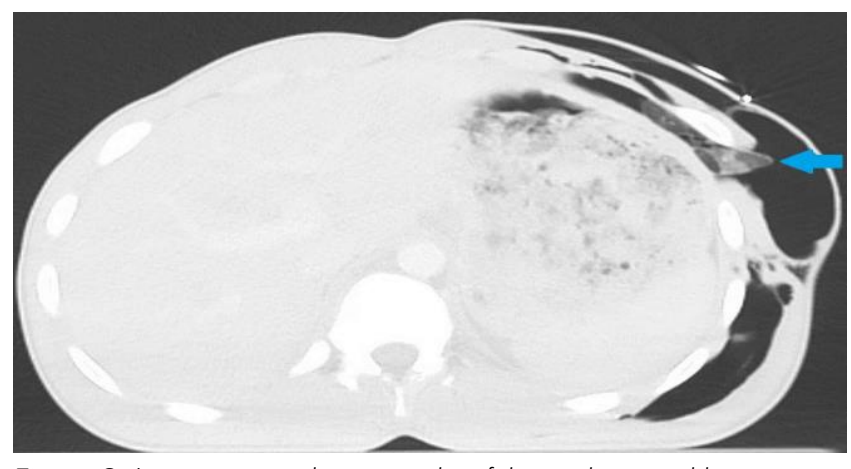

Figure 2: In computerized tomography of thorax, herniated lung tissue

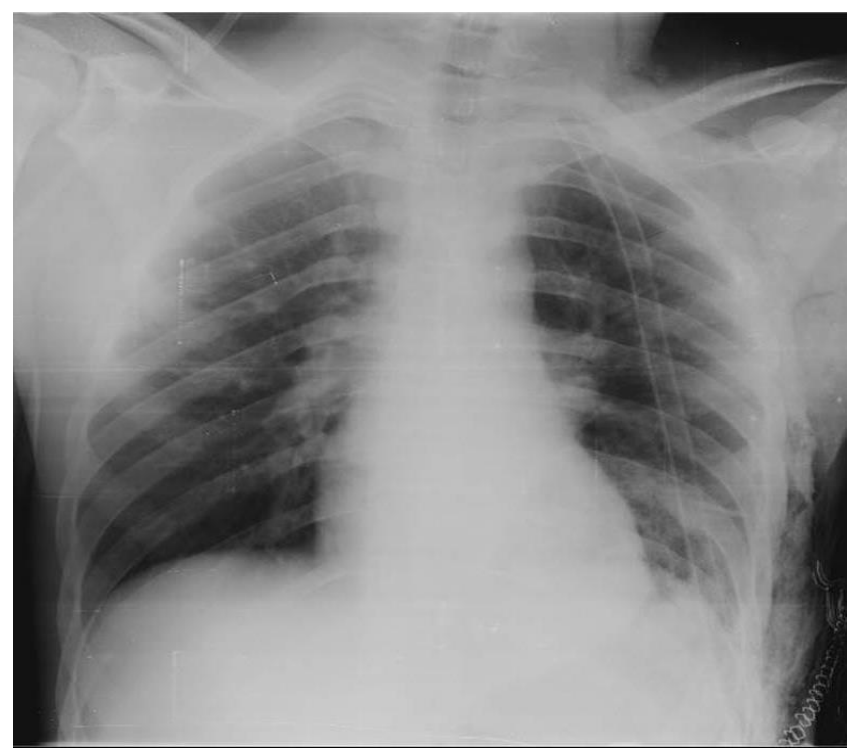

Figure 3: In postoperative lung graphy, it is observed that lung is expansed and subcutaneous emphysema is reduced

\section{DISCUSSION}

Herniations of the lung are classified according to anatomic location, such as mediastinum, diaphragmatic, thoracic and cervical (4). Etiological categorizations suggest that lung herniations may be acquired or congenital, while pathological, spontaneous, consecutive or traumatic are further classifications of acquired lung herniations (5).

Traumatic herniation, caused by the vulnerability of the thoracic wall, is a development that is observed secondary to a surgical operation, a chest-penetrating wound, rib fracture, etc.

A lung tissue herniation can result from an injury to the intercostal muscles together with an abrupt or continuous intrathoracic pressure increment. Herniation of the lung by a nonexistent fracture is apt to develop in the anterior or posterior areas where there are fewer layers of intercostal muscles. A lateral herniation in particular is an atypical occurrence due to the additional lateral reinforcement provided to the thoracic wall' provided by the serratus muscle. A literature search reveals only one case of lateral herniation that resulted from a high-energy motorcycle crash that elicited multiple concomitant rib fractures (6). In the present case, the patient suffered from a lateral lung herniation associated with a blunt thoracic trauma.

In general, a soft crepitant protrusion that is reducible on silent respiration accompanies diagnosis, which again protrudes forward with coughing or maneuver of the Valsalva (1).

In cases where a herniation of the lung is evident instantly, pain, coughing, hemoptysis and breathlessness are among the symptoms. A fluctuating mass with a superimposed crepitus that makes a paradoxical movement with respiration exposes in examination $(1,4)$. In our case, the primary symptoms were labored breathing, coughing and pain.

Since it may go unnoticed in routine chest radiography, a planum chest radiography performed during a Valsalva maneuver may be the first indication of a diagnosis of lung herniation.

Transthoracic USG, which is a viable diagnostic procedure for thoracic wall diseases such as pneumothorax, pulmonary consolidation and atelectasis, may provide useful information for a differential diagnosis (7).

A CT scan can be useful in the acquisition of valuable information regarding the size of the intercostal opening of the thoracic wall and the remaining thorax structures (6). Given that a prominent thoracic wall hematoma was detected on admission, pertinent traumatic injuries should have been suspected and a CT scan should have been requested earlier (8). To begin with, our patient underwent PA lung radiography, and a thoracic CT was requested thereafter in order to identify any correlation between the herniated lung tissue and the adjacent structures.

In a differential diagnosis of a palpable mass on the chest wall, subcutaneous emphysema, bronchopleural fistula, lipoma, thoracic wall abscess, skin metastasis, seroma and pectoralis major tendon ruptures are taken into consideration (9).

Since hernias rarely heal spontaneously, surgical therapy is usually necessary. There is still a lack of consensus on the timing of such surgery. While some suggest surgery as soon as a diagnosis (primary) has been established, others claim that timing should depend on the patient's general condition after waiting for a while (secondary) (10). In symptomatic lung hernias, the treatment route is surgical. The form of surgical intervention may vary, depending on the size of the herniation, whether strangulation is 
present, or whether there a paradoxical ventilation disturbance exists that is contingent upon respiration. In minor traumatic hernias, conservative methods may be appropriate (11). In the present case, we took the decision to operate since a trauma-induced symptomatic lung herniation was present.

In the operative surgery method, first, the lung is released by separating it from the surrounding soft tissue and reduced into the thoracic cavity. Defects to the skeletal structure are fixed with appropriate sutures, after which the herniation site is covered with soft prosthetic grafts such as Marlex mesh or vicryl before closing the dermis, and the supra structure of the defect is reinforced with the surrounding tissues (12). Surgical therapy produces perfect results. In our patient, the herniated lung tissue was reduced into the thorax by way of an anterolateral thoracotomy, and no prosthetic materials were used at the herniation site.

\section{CONCLUSIONS}

Extrathoracic lateral herniation of the lung is an atypical incidence that is associated with a wide range of severities, causes, complications and associations. In symptomatic lung hernias induced by blunt thorax traumas, we are of the opinion that a decision for surgical operation be made as soon as a diagnosis is established.

\section{CONFLICTS OF INTEREST}

None declared.

\section{AUTHOR CONTRIBUTIONS}

Concept - E.A., M.A.H., Ö.S.D.; Planning and Design E.A., M.A.H., Ö.Ş.D.; Supervision - E.A., M.A.H., Ö.Ş.D.; Funding - M.A.H., Ö.Ş.D.; Materials - E.A., Ö.S.D.; Data Collection and/or Processing - E.A., M.A.H.; Analysis and/or Interpretation - E.A., M.A.H., Ö.Ş.D.; Literature Review - E.A., Ö.Ş.D.; Writing - E.A., M.A.H.; Critical Review - E.A., M.A.H., Ö.Ş.D.

\section{YAZAR KATKILARI}

Fikir - E.A., M.A.H., Ö.Ş.D.; Tasarım ve Dizayn - E.A., M.A.H., Ö.Ş.D.; Denetleme - E.A., M.A.H., Ö.Ş.D.; Kaynaklar - M.A.H., Ö.Ş.D.; Malzemeler - E.A., Ö.Ş.D.; Veri Toplama ve/veya İşleme - E.A., M.A.H.; Analiz ve/veya
Yorum - E.A., M.A.H., Ö.S.D.; Literatür Taraması - E.A., Ö.Ş.D.; Yazıyı Yazan - E.A., M.A.H.; Eleştirel İnceleme E.A., M.A.H., Ö.Ş.D.

\section{REFERENCES}

1. Weissberg D, Refaely Y. Hernia of the lung. Ann Thorac Surg 2002; 74:1963-6. [CrossRef]

2. Athanassiadi K, Bagaev K, Simon A, Haverich A. Lung herniation: a rare complication in minimally invasive cardiothoracic surgery. Eur J Cardiothorac Surg 2008; 33:774-6. [CrossRef]

3. Lang-Lazdunski L, Bonnet PM, Pons F, Brinquin L, Jancovici R. Traumatic extrathoracic lung herniation. Ann Thorac Surg 2002; 74:927-9. [CrossRef]

4. Getzoff A, Shaves S, Carter Y, Foy H. Traumatic lung herniation. AJR Am J Roentgenol 1999; 172:1032. [CrossRef]

5. Detorakis E.E, Androulidakis E. Intercostal lung herniation - the role of imaging. Radiology Case 2014; 8:16-24. [CrossRef]

6. Petteruti F, Pepino P, De Luca G, Griffo S, Di Tommaso L, Stassano $P$. An unusual case of lateral pulmonary hernia. J Thora Cardiovasc Surg 2006; 132:189-90. CCrossRef

7. Marlow S, Campbell T, Davis A, Patel HR. Emergency ultrasound in the diagnosis of traumatic extrathoracic lung herniation. Am J Emerg Med 2013; 31:633. [CrossRef]

8. Clark AJ, Hughes N, Chisti F. Traumatic extrathoracic lung herniation. Br J Radiol 2009; 82:e82-4. [CrossRef]

9. Sainathan S, Pugalenthi A, Danovich S, Fox S, Andaz S. Image of the month. Intercostal lung hernia. Arch Surg 2012; 147:783. [CrossRef]

10. De Wijs MJ, Verhagen AF, Tan EC. Post-traumatic lung herniation. Ned Tijdschr Geneeskd 2012; 156:4863.

11. Bikhchandani J, Balters MW, Sugimoto JT. Conservative management of traumatic lung hernia. Ann Thorac Surg 2012; 93:992-4. [CrossRef]

12. Shields TW. Lung hernias of the chest wall. In: Shields TW, Lo Cicero III J, Reed CE, Feins RH, eds. General Thoracic Surgery. 7th ed. Philadelphia: Lippincott Williams \&Wilkins; 2009:629-32 